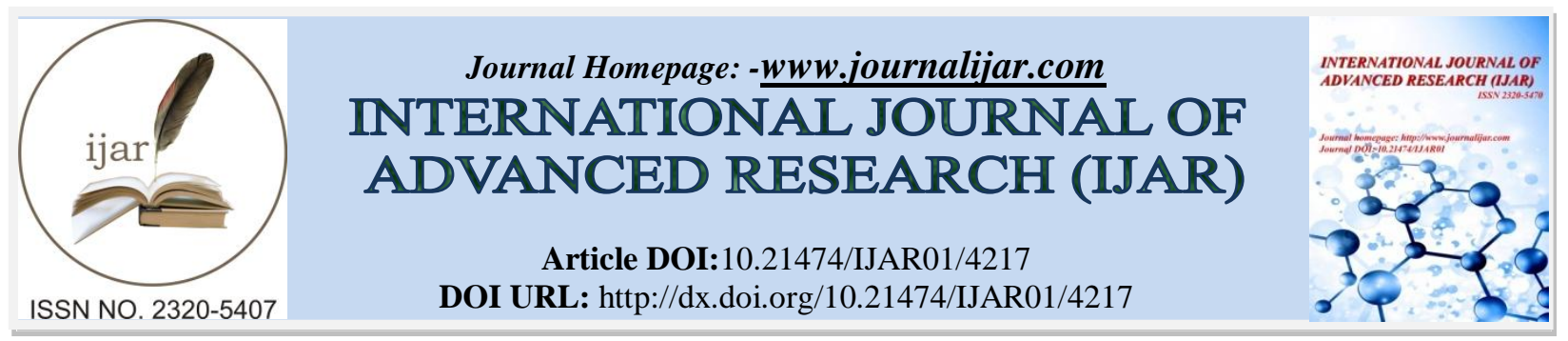

RESEARCH ARTICLE

\title{
THE EFFECT OF FEATURES OF AGRICULTURAL RADIO AND TELEVISION PROGRAMS ON FARMERS' FOLLOW UP TO THESE PROGRAMS IN SUDAN.
}

Mohamed ZakariaYahia ${ }^{1}$, AbdelRaouf Suleiman Bello ${ }^{2}$ and Ali Mohayad Bannaga ${ }^{1}$.

1. Department of Agricultural Extension and Rural Development, Faculty of Agriculture, University of Khartoum, Sudan.

2. Department of Agricultural Extension and Rural Society, College of Food and Agriculture Sciences, King Saud University, Kingdom of Saudi Arabia and Department of Agricultural Extension and Rural Development, Faculty of Agriculture, University of Khartoum, Sudan.

\section{Manuscript Info}

Manuscript History

Received: 17 March 2017

Final Accepted: 20 April 2017

Published: May 2017

Key words:-

Agriculture; radio and TV programs; agricultural technology; Sudan.

\section{Abstract}

This study was conducted to assess the effect of features of radio and television agricultural extension programs on farmers' in Sudan. A quota sampling method was used to select 840 respondents' farmers from six states (Khartoum, North Kordofan, Northern State, Kassala, Sennar, and West Darfur State). Primary data obtained through interview schedule. Descriptive analysis was carried out to display frequencies and percentages of socio-economic characteristics and communication behavior of respondents. Lambda, Cramer's V weight, and Kendall's tau-b techniques were used for data analysis and discussion. The study findings revealed that features of agricultural radio and television programs such as the broadcast time, program language, availability of a contact address, and quality of some types of agricultural technologies had significant positive effect on farmers' level of follow-up to these programs. On the other hand, $48.9 \%$ and $58.6 \%$ of the respondents did not follow agricultural programs on the radio and television respectively due to five main reasons, namely; don't have radio and/or television, don't know programs, no time to follow, not have a local transmitter, and no desire. The study recommended some interventions and measure to improvethe agricultural extension programs in the studied states.

Copy Right, IJAR, 2016,. All rights reserved.

\section{Introduction:-}

In most of the courtiers of the world, agriculture is a major contributor in terms of Gross Domestic Product (GDP) and employment particularly in rural areas; in addition, it has the capacity to reduce poverty in rural areas (Khan et al., 2010). According to Eltayb, (2010Agricultural extension is the most important factor for sustainable agricultural development and transformation from a traditional to a modern system through expanding and enhancing the farmers' knowledge, attitudes and skills. To Yahaya, (2003), there are various methods which can use by extension system include, personal instruction through home visit and farm visit, group methods such as video , workshop, group discussion, demonstration, and field day, mass media such as radio, television and printed publications such as posters, instruction leaflet, calendar and hand bill. 
Agricultural extension in developing countries faces various challenges and/constraints. Such constraints include inter alia two main problems :a- Farmers in Africa live in areas, where there is lack of basic infrastructures, such as good road network or access roads for regular visits by extension officers, hence this caused poor public relationship between the extension staff and the farmers(Obidike, 2011) and b- Few number of extension workers: Extension services face obstacles, including limited staff who must reach large numbers of geographically dispersed farmers(the ratio of agricultural extension workers to farmers is low). Agent-to-farmer ratios are extremely high, for example: as high as 1:6,000 in Ghana and the majority of small, marginal farmers worldwide receive only one-third of all extension resources. For the small fraction of rural farmers who are reached, visits are often inadequate for many reasons, including under skilled agents with limited accountability (Schmidt et al., 2012).

In absence of conventional extension services, one alternative is the use of mass media in the form of leaflets, pamphlets, TV, and radio (Turongruang and Demaine, 2000). According to Prathap and Ponnusamy (2006) in developing countries, the low "extension worker - farmer" ratio is resulting in less direct contacts between the change agents and farmers. Deficient information has always impeded growth and development in the rural sector and mass media may have to discharge the duty of technology transfer more intensively. Information, as we know is the key to success in the operation and management process of the agriculture activities. According to Hassan et al., (2011) mass media are important in providing information for enabling the rural community to make an informed decision regarding their farming activities, especially in the rural areas of developing countries. There are several studies confirmed this argument, in Nigeria, for example, the use of mass media is particularly necessary because farmers outnumber available extension workers with the present ratio of 1:3000 in Nigeria (Ozowa, 1997). However, Yahaya and Badiru (2002) reported that in Nigeria as in many countries, limited numbers of extension agents (one to 4,000 farmers) make it impossible to reach all farmers by interpersonal means, mass media alternative to reaching large numbers of farmers are an essential supplement. Moreover, With the shortage of extension personnel, the inaccessibility of large numbers of farmers living in remote areas and poor transportation facilities, farmers' access to new information is limited. It has been estimated that, on regular basis, most extension technicians can only serve 50 to 100 families from the all household population of 210,000. Farmers not within extension service areas will have to learn indirectly from others, use of communication media as means may play the main role to motivate farmers to adopt agricultural innovations in the Mekong Delta (Escalada et al., 1999). The mass media agricultural program is very important to cover all farmers by extension services (Haj, 2000; Yahia, 2007). As commented by Akkermans, (2010) in Ghana the ratio of extension workers to farmers is estimated to be 1 to 2000, but in recent years the number of agricultural extension Workers has been going down, while the numbers of farmers are growing. This means the role of the extension workers in the dissemination of knowledge within the rural communities is diminishing.

Generally, the mass-media is very important in agricultural extension communication for its following advantages:1Mass media are spreading agricultural technologies to the farmers at a faster rate than personal contacts. At the same time, this methodology can serve many farmers with necessary and important information on time; 2-These media generally are the least expensive media to carry the message to a large number of people). The cost of extension advice through mass media comes to be considerably low as compared to individual and group methods). Mass media are low cost. The cost of extension advice through mass media comes to be considerably low as compared to individual and group methods, for example: the World Bank has conducted studies on the cost- effectiveness of various mass media, which reveal that the initial costs of certain media may appear higher, but in terms of overall costs of reaching the farmers, the media are much cheaper; 3-Mass media, such as radio, television, print and recently, new media such as the Internet have been playing a role in imparting knowledge, information, an important farm technologies, methods and practices to the farming community at the right time. Their potential for influencing knowledge gain, public attitude and behaviors has been well recognized through several research studies; 4 -There are doubts have been cast on their effectiveness of mass media in influencing decision-making, as opposed to creating awareness of innovations and stimulating their interest in them, a distinction should be made here between audio-visual and printed materials. This can be complementary in that the former may be used to create awareness, while the latter supply a constant reference as a person can keep a leaflet and refer to it any time ( Creation of awareness is the first step towards the adoption process, mass media (electronic \& print media) are playing very important role in creating awareness about new agricultural technologies among farmers; 5- Extension programs in Mass media such as radio and television, are important to deliver information technologies to smallholder farmers, whom the public extension services did not reach them due to extension is dramatically underfunded, and 6- The potential of mass media for influencing knowledge gain, public attitude and behavior has been well recognized 
through several research studies(Hoi, 2007;(Turongruang and Demaine, 2000; Prathap and Ponnusamy, 2006;Eicher, 2007; Butt et al., 2008;and IRFAN et al., 2006).

It is worth mentioning that all channels of communication are not preferred equally by farmers, preference depends largely on how farmers have been sensitized to a particular channel (Saadi et al., 2009).For the success of mass media agricultural programs, there are four main important requirements which should be taken into account:1Today, generation new and various information and multi sources of knowledge need better selecting information, and designed more effectiveness of extension programs in agriculture. According to Hoi (2007)the first step of transfer of technical innovations for farmers in remote areas, is: Identification of farmers' problems, needs, and interests: (What problems that farmers need to solve? What are difficulties and potentials of farmers insolving theseproblems? Participation and commitments of farmers in solving the problems; 2-Proper selection for language of program: a- Choose the appropriate language. The program of agriculture must take into account the educational level of farmers' category, with use of easy sentences and words which are common used among farmers and avoid the use of complex scientific terms (Tanobi, 1995); b-theories of communication say that the success of the language of communication or its effectiveness will assist in: i- understanding of the message, ii- Knowledge gain iiiperception of the, and vii- ego- involvement (Prathapand Ponnusamy, 2006). Chauhan, (2007) reported that necessary characteristics for a good message or program, such as: 1-Clearly understandable by the audience.2-The message must be according to the traditions, needs and desires of the audience.3- Choose the right time to broadcast the extension programs to the farmers: Time is chosen according to the following (Tanobi, 1995): a-The nature of agricultural work; b-Social reality of the target group; c- Psychological readiness to receive the program; d-Season of the year and climate; e-Crop and season; f-Simplification, marketing and promotion (persuasion), and gRegularity of the program in time of broadcast, its continuation and persistence.4- Provided some communication means such as: telephone number, e-mail...etc., to receive receivers' questions, to answer these questions, and to discuss the suggestions, so that to overcome the apparent shortage of one way communication of mass media which involve one-way communication from information source to the receivers; they permit limited and delayed feedback, which of course is essential for effective communication (Butt et al., 2008; IRFAN et al., 2006).Figure 1 shows four main important requirements of success of mass media agricultural programs. There are several Radio and TV agricultural extension programs and station throughout the country. Table 1 shows some of such programs in selected states.

Figure 1:-Overlapping factors affecting the success of mass media agricultural programs.

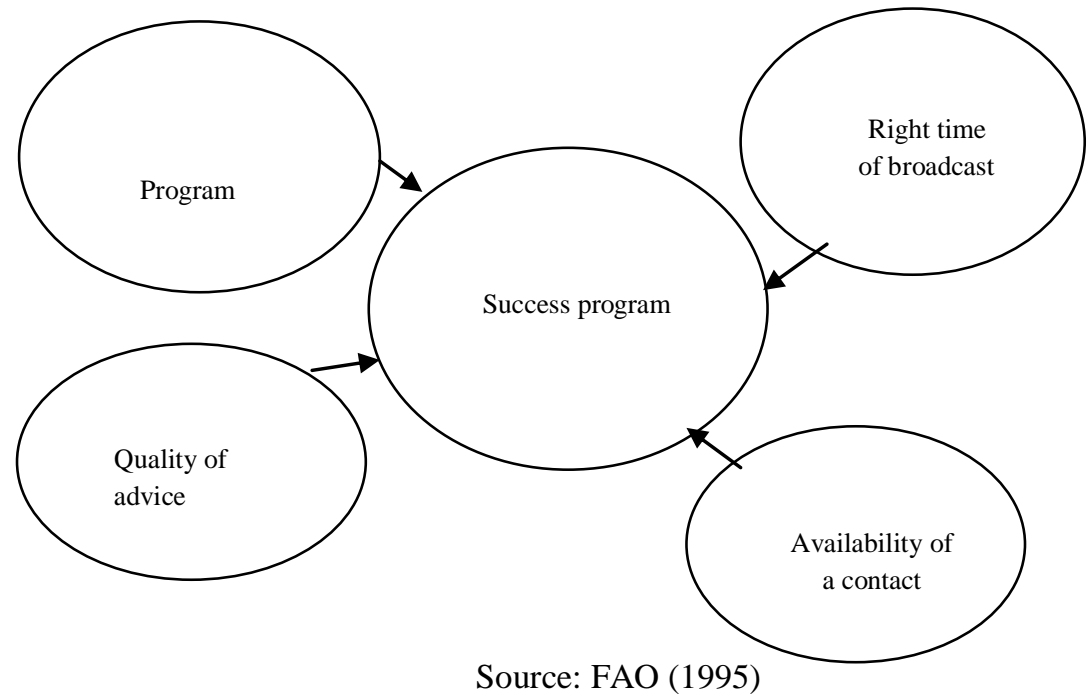

\section{Objectives ofthe Study:-}

Source: FAO (1995)

The major objective of this study was to evaluate the effect of features of the agricultural radio and television (TV) programs on farmers' follow up to these programs. The specific objectives were to:

1. Identify the level of follow-up to agricultural radio and TV programs as main sources of agricultural information for farmers. 
2. Examine the relationship between some features of the radio and TV programs (such as: the time of broadcast, program language, availability of a contact address, and quality of advices) and farmers' level of follow-up to these programs.

3. Propose some recommendation based on findings, for programs development and improvement.

\section{Methodology:-}

\section{Study Area:-}

This study was carried out to evaluate the effect of features of radio and television agricultural extension programs on farmers' in Sudan, with major and contrasting agricultural environments and farming systems. These states are Khartoum, North Kordofan, Northern State, Kassala, Sennar, and West Darfur State (table 1 and 2).

Table 1:- Summary of basic Information and Agricultural Resources of the Study Area.

\begin{tabular}{|c|c|c|}
\hline State/Reference & Location, area, and population & Agricultural lands/ Weather \\
\hline $\begin{array}{l}\text { Khartoum } \\
\text { (Agric.Planning Adm. } \\
\text { 2003) }\end{array}$ & $\begin{array}{l}\text { The stated located between lat. } 10^{\circ} 8^{-} \text {and } \\
18^{\circ} 39^{-} \text {North and long } 31^{\circ} 36^{-} \text {and } 34^{\circ} \\
25^{-} \text {East. The area: } 21000 \text { Sq. km. } 5.3 \\
\text { million People. }\end{array}$ & $\begin{array}{l}\text { Agric lands: approx. } 1.8 \text { million feddans. } \\
\text { The weather: Semi-desert very hot in } \\
\text { summer and mild in winter. Surface water } \\
\text { from the Blue and white Nile. Average rain } \\
\text { fall } 150 \mathrm{~mm} / \text { year }\end{array}$ \\
\hline $\begin{array}{l}\text { Northern state } \\
\text { (Agric. } \\
\text { PlanningAdm.2012) }\end{array}$ & $\begin{array}{l}\text { The stated located between lat. } 16^{\circ} \text { and } 22^{\circ} \\
\text { North and long } 22^{\circ} \text { and } 32^{\circ} \text { East. The area: } \\
348697 \text { sq. km. } 699.65 \text { thousand People. }\end{array}$ & $\begin{array}{l}\text { Agric lands: } 110 \text { million feddas. The } \\
\text { weather: Cold winter and very hot in } \\
\text { summer up to } 49^{\circ} \text {. Surface water from River } \\
\text { Nile and some Wadies and Khors. Rain fall } \\
\text { very little and rave about } 100 \mathrm{~mm} / \text { year. }\end{array}$ \\
\hline $\begin{array}{l}\text { North Kordufan } \\
\text { (Agric. } \\
\text { PlanningAdm.2011) }\end{array}$ & $\begin{array}{l}\text { The stated located between lat. } 11^{\circ} 10^{-} \text {and } \\
16^{\circ} 45^{-} \text {North and } 27^{\circ} 5^{-} \text {and } 32^{\circ} 15^{-} \text {East. } \\
\text { The area: Equivalent to } 58.7 \text { million } \\
\text { feddans. } 2.4 \text { million People }\end{array}$ & $\begin{array}{l}\text { Agric lands: } 89 \text { million feddens. The } \\
\text { weather: Four major zones: The desert }(0- \\
\left.75 \mathrm{~mm}^{3}\right) \text {, semi desert }\left(75-300 \mathrm{~mm}^{3}\right) \text {, low } \\
\text { rainfall Savannah in the sandy soils ( } 30- \\
\left.400 \mathrm{~mm}^{3}\right) \text {, and low rain fall Savannah in the } \\
\text { clay soils }\left(400-500 \mathrm{~mm}^{3}\right) \text {. }\end{array}$ \\
\hline $\begin{array}{l}\text { Sennar } \\
\text { (Agric. } \\
\text { PlanningAdm.2011) }\end{array}$ & $\begin{array}{l}\text { The stated located between lat. } 11^{\circ} \text { and } 14^{\circ} \\
\text { North and } 32^{\circ} \text { and } 36^{\circ} \text { East. The area: } \\
40680 \mathrm{sq} . \mathrm{km} .1285058 \text { people. }\end{array}$ & $\begin{array}{l}\text { Agric. lands: a) rain-fed } 5.5 \text { million feddans. } \\
\text { b) irrigated } 225 \text { thousand feddans. The } \\
\text { weather: Between rich and poor savannah } \\
\text { with } 2 \text { seasons: Hot Summer } 35-41^{\circ} \text { and } 12- \\
25^{\circ} \text { Winter. Rainfall decrease from North to } \\
\text { South from } 400-600-800 \mathrm{~mm} / \text { year. }\end{array}$ \\
\hline $\begin{array}{l}\text { West Darfur } \\
\text { (Agric.PlanningAdm. } \\
\text { 2012 ) }\end{array}$ & $\begin{array}{l}\text { The stated located in western Sudan?. The } \\
\text { area: } 75 \text { thousand sq. km. } 2085343 \text { people }\end{array}$ & $\begin{array}{l}\text { Agric. Lands: } 20 \text { million Feddans. The } \\
\text { weather: Semi desert in the north, high } \\
\text { rainfall Savannah in the south, } \\
\text { Mediterranean weather in Jebel Marra, and } \\
\text { high rainfall from } 800-1000 \mathrm{~mm} \text {. }\end{array}$ \\
\hline $\begin{array}{l}\text { Kassala } \quad \text { (Agric. } \\
\text { PlanningAdm. 2007) }\end{array}$ & $\begin{array}{l}\text { The stated located between lat. } 14^{\circ} 45^{-} \text {and } \\
17^{\circ} \text { North and } 34^{\circ} 40^{-} \text {and } 37^{\circ} \text { East. The } \\
\text { area: } 42282 \mathrm{sg} . \mathrm{Km} .1527214 \text { people. }\end{array}$ & $\begin{array}{l}\text { Agric. Lands: } 3.6 \text { million feddans. The } \\
\text { weather: North East winds in Winter and } \\
\text { South West winds in Summer. The } \\
\text { temperature average between } 32-47^{\circ} \text {. } \\
\text { Average rain fall between } 100-150 \mathrm{~mm} \text {. }\end{array}$ \\
\hline
\end{tabular}

Table 2:- Summary of Agricultural Programs of Radio and TV Stations in the study area.

\begin{tabular}{|c|l|l|}
\hline State & \multicolumn{1}{|c|}{ Radio the Agric. Program } & \multicolumn{1}{|c|}{ TV the Agric. Program } \\
\hline Khartoum & $\begin{array}{l}\text { HigoolWaGirouf :Operating since 1990. Broadcast at 11 } \\
\text { a.m. every Saturday. Period: 20-40 minute. }\end{array}$ & $\begin{array}{l}\text { 1.Zoraa WaZorra: (1990 -2002), 2.Sihool } \\
\text { AlKhair 2003-2005, and 3.AlMagalla } \\
\text { Alzirraeia: 2006-now Broadcasting Tuesday } \\
\text { at 12 noon for 30 minute }\end{array}$ \\
\hline \multirow{2}{*}{ Northern } & $\begin{array}{l}\text { MisahaKhadra: Since2007 (5 years) broadcasting at } \\
\text { 5.30p.m every Tuesday. Period: 45 minute. }\end{array}$ & $\begin{array}{l}\text { TaganatZirraeia: 2007-nown (5 years) } \\
\text { *Broadcasting Every Tuesday between 8.20- } \\
8.50 \text { am. }\end{array}$ \\
\hline
\end{tabular}




\begin{tabular}{|l|l|l|}
\hline Sennar & $\begin{array}{l}\text { 1-Hiwar Ziraai: Operating since 2010 (3years), } \\
\text { Broadcasting: Half Monthly (15 minute) } \\
\text { 2-Kapsula Irshadia: Operating since 2005 (7years), } \\
\text { broadcasted daily morning (3-4minute). }\end{array}$ & $\begin{array}{l}\text { Almagalla Alzirraeia:1998 - Up-to-date (14 } \\
\text { years).Broadcasting every Wednesday at 8 } \\
\text { a.m. for 25 minutes }\end{array}$ \\
\hline $\begin{array}{l}\text { North } \\
\text { Kordofan }\end{array}$ & $\begin{array}{l}\text { AlardAlwaida:Operating since 2007(5 year) } \\
\text {-Broadcast on Wednesday at 7.10 pm (15 minute). }\end{array}$ & $\begin{array}{l}\text { Ard Al Khair:One year daily on Sundays at } \\
7.30 \text { for 15 minutes. }\end{array}$ \\
\hline WestDar fur & $\begin{array}{l}\text { HigoolWaSihool:(2003-2006) Every Monday at 4.30 } \\
\text { pm, and stopped now, but there are community radio } \\
\text { program at that time (30 minute). }\end{array}$ & -Not. \\
\hline Kasala & $\begin{array}{l}\text { 1.ArdAlKhir:Since 1991, on Sunday afternoon for 15 } \\
\text { minutes, 2.Ogash:Since 2009 year, on Tuesday } \\
\text { afternoon for 15 minutes, and 3.Kapsulat Zirraeia:Daily } \\
\text { between the regular programs (3-4minutes). }\end{array}$ & $\begin{array}{l}\text { Ardna Al Tayiaba: Start in 2002 -2009, } \\
\text { Broadcasting every Monday at 7:30 pm. }\end{array}$ \\
\hline
\end{tabular}

Source: Source: The General Corporation for radio and TV, Television sector in the study area- general official archives (2000- 2013).

\section{Data collection and Analysis:-}

The Population of the study represents all the farmers in the different agricultural sectors in the six states of the study. Quota sample was adopted to select 840 farmers (140 farmers from each). The Statistical Package for the Social Sciences (SPSS) was used to analyze the obtained data by implementing: (1) Descriptive analysis was carried out to display frequencies and percentages of socio-economic characteristics and communication behavior of respondents, and (2) analytical statistical procedures (Lambda, Cramer's V weight, and Kendall's tau-b) were used data analysis and discussion.

\section{Results and Discussion:-}

\section{Follow-up of Radio and Television Agricultural Programs:-}

Table4 shows that $51.1 \%$ of respondents followed the agricultural radio programs on three different frequency levels; rarely $(31.9 \%)$, sometimes $(46.9 \%)$, and continuously $(21.2 \%)$. Those who followed the programs rarely or/and sometimes commented that they have no time to the time of the program casting time is inconvenient for them. The table also indicates that $41.4 \%$ of respondents watched the agricultural TV programs on three frequency levels: rarely $(35.3 \%)$, sometimes $(48 \%)$, and continuously (16.7\%). Respondents who watch the TV agricultural programs either rarely or sometimes concluded that they have no time to watch continuously.

Data in Table 4 revealed that the scale of broadcasting time of the agricultural radio and TV programs had significant positive Cramer's V weight, which indicates that the time of broadcast has a higher effect on the farmers' level of listening and watching these programs. The results also indicate that the broadcasting time of agricultural radio programs had affected the farmers' level of listening by $26.5 \%$, while the broadcast time of agricultural TV programs had affected the farmers' level of watching by $21 \%$, indicating that the broadcast time of agricultural radio programs is more suitable to the farmers than the broadcasting time of agricultural TV programs. These results are in line with Arab Organization for Agricultural Development (AOAD) (1995), who reported that the right time to introduce the activity or program to farmers is one of the most important requirements which affect the success of agricultural extension activities or programs.

The results in table 5 displayed the language scale of agricultural radio and TV programs had significant positive Kendall's tau-b weight, indicating that the programming language had a high effect on the farmers' level of listening and watching to these programs. It is also indicated that the broadcast language of the two agricultural radio and TV programs was tailored to the language of the farmers, therefore, the programs were positively affected the respondents level of listening and watching. These results very much agree with literature (Sabri, 1997; Prathap and Ponnusamy, 2006; Chauhan, 2007). 
Table 3:- Summary of Frequency Distribution of Respondents According to their Follow-up to Radio and Television Agricultural Programs

\begin{tabular}{|c|c|c|c|c|}
\hline \multirow[b]{2}{*}{ The issue } & \multicolumn{2}{|r|}{ Radio } & \multicolumn{2}{|c|}{ Television } \\
\hline & Frequency & Percent & Frequency & Percent \\
\hline \multicolumn{5}{|c|}{ The follow-up } \\
\hline Yes & 429 & 51.1 & 348 & 41.1 \\
\hline No & 411 & 48.9 & 492 & 58.6 \\
\hline Total & 840 & 100 & 840 & 100 \\
\hline \multicolumn{5}{|c|}{ Level of follow-up } \\
\hline Rarely & 137 & 31.9 & 123 & 35.3 \\
\hline Sometime & 201 & 46.9 & 167 & 48 \\
\hline Continuously & 91 & 21.2 & 58 & 16.7 \\
\hline Total & 429 & 100 & 348 & 100 \\
\hline \multicolumn{5}{|c|}{ Reasons of not following the programs } \\
\hline Don't have radio/TV & 238 & 57.9 & 222 & 45.1 \\
\hline No know programs & 74 & 18 & 83 & 16.9 \\
\hline No time to follow & 61 & 14.8 & 72 & 14.6 \\
\hline No transmitter & 20 & 4.9 & 63 & 12.8 \\
\hline No desire & 18 & 4.4 & 52 & 10.6 \\
\hline Total & 411 & 100 & 492 & 100 \\
\hline
\end{tabular}

Table 4:- Summary of the Relationship between the Broadcasting Time of Agricultural Programs on the Radio and TV and Farmers' Level of Follow-up to these Programs

\begin{tabular}{|c|c|c|c|c|}
\hline \multirow{2}{*}{$\begin{array}{c}\text { Level of follow-up to agricultural } \\
\text { programs. }\end{array}$} & Value & Approx. Sig. & \multicolumn{2}{c|}{ VV } \\
\hline N & 0.265 & 0.000 & 0.210 & 0.000 \\
\hline & 429 & & 348 & \\
\hline
\end{tabular}

Table 5:- Summary of Relationship between the Language of Agricultural Radio and TV Programs and Farmers' Level of Listening to these Programs

\begin{tabular}{|c|c|c|c|c|}
\hline & \multicolumn{2}{|r|}{ Radio } & \multicolumn{2}{|r|}{$\mathrm{TV}$} \\
\hline & Value & Approx. Sig. & Value & Approx. Sig. \\
\hline $\begin{array}{l}\text { Level of follow-up to agricultural } \\
\text { programs. }\end{array}$ & 0.114 & 0.010 & 0.211 & 0.000 \\
\hline $\mathrm{N}$ & 429 & & 348 & \\
\hline
\end{tabular}

The results in Tables 6show that the scales of available of an address of agricultural radio and TV programs had significant positive Cramer's V weight, indicating that the available of an address of programs had a high effect on the farmers' level of listening and watching to these programs. The availability of an address for farmers to contact with the agricultural presenters is one of main reasons which increase the level of benefit of agricultural programs in mass media. This stems from the fact that the contact between the farmer audience and agricultural presenters will generate interaction and feedback by receiving famers' questions and comments. Consequently, the presenters will be better able to introduce programs based on farmers' problems, needs, and interests. In this regard Chauhan, (2007) commented that each transmitter wants a response to his or her message after its transmission, but sometimes he cannot get the desired response. If he does not get any type of response, it means that the communication process was not successful and that the message did not reach the receiver. The opportunity to receive feedback to mass media programs is very important to create interaction between the program and the farmers to receive inquiries, respond to inquiries and discuss relevant proposals (Yahia, 2007; Olaleye et al.; 2009; Schmidt et al., 2012). 
Table 6:- Summary of Relationship between the Availability of a Contact Address for Agricultural Radio and TV Programs and Farmers' Level of Follow-up to these Programs

\begin{tabular}{|c|c|c|c|c|}
\hline \multirow{2}{*}{$\begin{array}{c}\text { Level of follow-up to agricultural } \\
\text { programs. }\end{array}$} & Value & Approx. Sig. & \multicolumn{2}{c|}{ VV } \\
\hline $\mathrm{N}$ & 0.133 & 0.023 & 0.203 & 0.001 \\
\hline & 429 & & 348 & \\
\hline
\end{tabular}

Finding in table 7 on scales of five types of agricultural technologies, including seed varieties, harvest, post-harvest, marketing, and problem solving had significant positive Kendall's tau-b weight, indicating that the quality of these agricultural technologies had a high effect on the farmers' level of listening. The table also shows that scales of five types of agricultural technologies: land preparation, sowing, irrigation, fertilizer use, and weeding had no significant positive Kendall's tau-b weight. It is also indicated that the scale of one type of agricultural technology, control of pests and diseases, had no significant negative Kendall's tau-b weight, indicating that the quality of this technology only had a low effect on the farmers' level of listening. These results reflect the fact that agricultural radio programs introduced information about different types of agricultural technologies. The reason of high satisfaction with the technologies of seed varieties, harvest, post-harvest, marketing, and problem solving, may be due to the fact that the radio programs had delivered much information on these technologies, hence these technologies had have high effect on farmers' levels of listening to the programs. On the other hand, the reason of low satisfaction with the technology of control of pests and diseases, may resulted from the fact that the information about of this technology was not enough to solve the farmers' problem or may not suitable to their situation, hence this technology have had less effect on farmers' levels of listening. Generally these results illustrate the importance of the program(s) content to encourage farmers up. These results are in line with Chauhan, 2007 who commented that the message delivered must be designed according to the traditions, needs and desires of the audience. In this regard AOAD,( 1995) indicated that the program should deal with one topic at a time, so as to not confuse the recipient and, in consideration of the matters which affect the lives of farmers, their fields and productivity, until farmers realize the value and importance of these programs.

Data in 8showson the scales of two types of agricultural technologies (control of pest and diseases and problemsolving) had significant positive Kendall's tau-b weight, indicating the quality of these agricultural technologies, had a high effect on farmers' level of watching. The table also indicates that the scales of five types of agricultural technologies (land preparation, seed verities, fertilizer use, harvest, and marketing) had none significant positive Kendall's tau-b weight. It is also revealed that the scales of three types agricultural technologies (irrigation methods, weeding, and post-harvest) had none significant negative Kendall's tau-b weight. The scales of one type of agricultural technology (owing method) had significant negative Kendall's tau-b weight, indicating the quality of this agricultural technology, had a very low effect on farmers' level of watching. The findings also indicate that the agricultural TV programs had displayed different types of agricultural technologies. The reason for high satisfaction with the technologies of control of pests and diseases and problem-solving resulted from the fact that the programs had delivered much information about these two technologies, which have a high link with farmers' needs and problem. Therefore, the information had has a high effect on farmers' levels of watching these programs. The reason for low satisfaction with the technology of sowing method may result limited information provided by the TV program about this technology or farmers have less interesting on this technology. It is, therefore, had has less effect on farmers' levels of watching.

Table 7:- Summary of Relationship between the Farmers' Levels of Satisfaction with the Quality of the Advice Provided by Agricultural Radio Programs and their Following of these Programs

\begin{tabular}{|c|c|c|}
\hline Agricultural advices & Scale of tau-b & Significance level \\
\hline Land preparation & $+0.073 \mathrm{NS}$ & 0.261 \\
\hline Seed verities & $+0.173^{* *}$ & 0.001 \\
\hline Sowing method & $+0.054 \mathrm{NS}$ & 0.430 \\
\hline Irrigation methods & $+0.052 \mathrm{NS}$ & 0.542 \\
\hline Fertilizer use & $+0.010 \mathrm{NS}$ & 0.851 \\
\hline Weeding & $+0.042 \mathrm{NS}$ & 0.644 \\
\hline Control of pest and diseases & $-0.032 \mathrm{NS}$ & 0.603 \\
\hline Harvest & $+0.245^{*}$ & 0.037 \\
\hline
\end{tabular}




\begin{tabular}{|c|c|c|}
\hline Post-harvest & $+0.339^{*}$ & 0.018 \\
\hline Marketing & $+0.390^{* *}$ & 0.001 \\
\hline Problem solving & $+0.185^{*}$ & 0.023 \\
\hline
\end{tabular}

Table 8:- Summary of Relationship between the Farmers' Levels of Satisfaction with the Quality of Advice Provided by Agricultural TV Programs and their Following of these Programs

\begin{tabular}{|c|c|c|}
\hline Agricultural advices & Scale of tau-b & Significance level \\
\hline Land preparation & $+0.040 \mathrm{NS}$ & 0.644 \\
\hline Seed verities & $+0.007 \mathrm{NS}$ & 0.898 \\
\hline Sowing method & $-0.137^{*}$ & 0.050 \\
\hline Irrigation methods & $-0.038 \mathrm{NS}$ & 0.658 \\
\hline Fertilizer use & $+0.065 \mathrm{NS}$ & 0.311 \\
\hline Weeding & $-0.055 \mathrm{NS}$ & 0.550 \\
\hline Control of Pest and diseases & $+0.211^{* *}$ & 0.002 \\
\hline Harvest & $+0.107 \mathrm{NS}$ & 0.188 \\
\hline Post-harvest & $-0.077 \mathrm{NS}$ & 0.533 \\
\hline Marketing & $+0.172 \mathrm{NS}$ & 0.226 \\
\hline Problem solving & $+0.131^{*}$ & 0.035 \\
\hline
\end{tabular}

\section{Conclusion and Recommendations:-}

In conclusion, there is regular agricultural programs transmission through radio and TV station in the six studied state in Sudan, some farmers follow these programs in different levels (continuously, sometimes, and rarely). The study findings revealed that features of agricultural radio and television programs such as the broadcast time, program language, availability of a contact address, and quality of some types of agricultural technologies have significant positive effect on farmers' level of follow-up to these programs. Result also indicated that some respondents do not follow the programs due to five main reasons; namely, they don't have radio/TV, don't know programs, no time to follow, no have a local transmitter, and no desire.

The study recommended that radio and TV agricultural programs should be broadcasted in suitable time for farmers and clear language, design of programs contents should be based on farmers' problems, needs, and interests, and the use of contact address (such as telephone number, e-mail...etc.) is very necessary to receive feedback and create interaction between listeners or viewers and presenters of the programs. To reduce reasons of not follow-up of radio and TV agricultural programs a package of activities should be adopted. These include: 1- The concerned government authorities should increase their effort to strengthen and improve the transmitters of radio and TV in the studied area, and provide the farmers with radio and TV sets through cooperation with local and international governmental and none governmental organizations involved in agricultural development; 2-Announcement about the programs before broadcasting and a repeat of the program in any other day within the particular week; and 3Encourage listening and watching of agricultural programs by the local extension agents who work directly with farmers in the field.

\section{References:-}

1. Agricultural Planning Administration, Ministry of Agriculture, Kassala state (2007). annual report: 59.

2. Agricultural Planning Administration, Ministry of Agriculture, Khartoum state (2003). annual report: 46.

3. Agricultural Planning Administration, Ministry of Agriculture, Northern state (2012). annual report: 52.

4. Agricultural Planning Administration, Ministry of Agriculture, North Kordufan state (2011). annual report: 61.

5. Agricultural Planning Administration, Ministry of Agriculture, Sennar state (2011). annual report.

6. Agricultural Planning Administration, Ministry of Agriculture, West DarFur state (2012). annual report: 44.

7. Akkermans, N. (2010) The Role of ICTs in Knowledge Sharing within Rural Communities in Ghana, MSc. Thesis, and University of Groningen Internship providing Organization: CIS at Vu University Amsterdam:167

8. Arab Organization for Agricultural Development (AOAD) (1995). the national training course in the preparation of agricultural information programs in the Arab World, Khartoum: AOAD Press: 285

9. Butt, T. M., S.T. Sahi, K. M. Chaudary and S. Muhammad (2008). Role of mass media for enhancing potato production in district Okara of Pakistan, Indian Res. J. Ext. Edu., 8(1): 16-18.

10. Chauhan, J. (2007). Communication in agriculture, R.B.S.College, Bichpuri, Agra-282007: 353. 
11. Eicher, C. K. (2007).Agricultural extension in Africa and Asia, paper presented in the World Ag Info Project, Cornell University, Ithaca, New York: 173.

12. Eltaib, A. Y. (2010). Challenges Facing the Adoption of Agricultural Technologies in the Rain-fed Area of White Nile State, Sudan, (Ph.D. thesis)., University of Khartoum, Faculty of Agriculture, Department of agricultural Extension and Rural Development: 112.

13. Escalada MM; Heong KL; Huan NH and Mai V.(1999). Communication and Behavior Change in Rice farmers' Pest Management: The case of Using Mass Media in Vietnam, Journal of Applied Communication, 83 (1): 7-26.

14. Haj, E. K. (2000). The role of the mass media in activating the process of adoption and modernization amongst the farmers of province east of Nile- Khartoum State, M.Sc. Thesis, Sudan University of Science and Technology - Faculty of Agricultural Studies: 168.

15. Hassan, S ; Yassin, S ; Mohamed, HA ; Othman, S; Abusamh, B, Abusamh, A,andRamli, A (2011). Receivingthe Agriculture Information through Mass Media and Interpersonal Sources among the Rural Community, American Journal of Agricultural and Biological Sciences 6 (3):451-461.

16. Hoi, D. (2007). Participatory agricultural extension methodology (PAEM), Department of Agriculture and Rural Development, Quang, Binh Province: 64.

17. Khan, GA; Muhammad,S, and Chaudhary, KM (2010). Present Status and Future Preferences of Electronic Media as Agricultural Information Sources by the Farmers, Pak. J. Agri. Sci., 47(2), 166-172.

18. IRFAN, M; Muhammad, S; Khan, GA and Asif, M(2006). Role of Mass Media in the Dissemination of Agricultural TechnologiesAmongFarmers, International journal of agriculture \&biology, 1560-8530: 417-419.

19. Obidike, N, A (2011). Rural Farmers' Problems Accessing Agricultural Information: A Case Study of Nsukka Local Government Area of Enugu State, Nigeria, Library Philosophy and Practice, ISSN 1522-0222.

20. Olaleye, R.S; Gana,F.S; Umar,I S,N, danisa,M.A and Peter, E.W.(2009). Electiveness of Radio in in the Dissemination of Agricultural Information among FarmersInedulocal Government Area of KwaraState,NIGERIA, Continental J. Agricultural Science3:1- 6.

21. Ozowa, V. N. (1997). Information Needs of Small Scale Farmers in Africa: The Nigerian Example, Consultative Group on International Agricultural Research, 4(3).

22. Prathap, D. P and Ponnusamy, K. A. (2006). Effectiveness of Four Mass Media Channels on the Knowledge Gain of Rural Women, Journal of International Agric. And Extension Edu., 13: 73.

23. Saadi, H; Prakasha, ,K, and Stevens, J. (2005). Surveying on Wheat Farmers' Access and Confiedence to Sources of Information and Communication Channels (ICTS) About Controlling Eurygasterintegriceps in HamedanProvince of IRAN, paper presented in $22^{\text {nd }}$ Annual Conference Proceedings, Clearwater Beach, Florida: 87.

24. Saleh, S. M. (1997) Agricultural Extension: Methods and Educational Aids, (first edition) University of Omar Al-Mukhtar: 416.

25. Schmidt, C S; Gorman, T J; Gary, M S, andBayor A A,(2012). Impact of Low-Cost, On-Demand Information Access in a Remote Ghanaian Village, USCA nnenberg School for Communication \&Communication \&Journalism, 8(2):85-100.

26. Tanobi, M. O. (1995) Reference in the Information and Agricultural Information, Alexandria: 196.

27. The General Corporation for radio and TV, Radio sector in the study area- (2000-2013) general official archives: 234

28. The General Corporation for radio and TV, Television sector in the study area (2000-2013) general official archives: 205

29. Turongruang ,D, and Demaine, H. (2000) Participatory Development of Aquaculture Extension Materials and Their Effectiveness in Transfer of Technology :the Case of the AIT Aqua Outreach Program, North east Thailand, paper presented in The Fifth Asian Fisheries Forum, International Conference on Fisheries and Food Security,ChiangMai,Thailand:1-12

30. Yahaya, M.K. (2003) Development Communication: Lessons from Change and Social Engineering Projects. Corporate Graphic Publishers, Ibadan. ISBN 978-36756-2-1 (100\%): 240.

31. Yahia, M. Z. (2007) The Effectiveness of Mass-media on Agricultural Development (A Case:KassalaStateSudan), M.Sc., University of Khartoum, Faculty of Agriculture: 177. 